\author{
Nina ISHCHENKO \\ Belarusian branch of International Slavic Law Academy \\ ni875@yandex.ru
}

ORCID 0000-0002-4157-1876

Jacek ZIELIŃSKI

Siedlce Universityy of Natural Sciences and Humanities

Faculty of Social Sciences

jacek.zielinski@uph.edu.pl

ORCID 0000-0002-5630-0606

https://doi.org/10.34739/dsd.2020.01.15

\title{
ПРОДОВОЛЬСТВЕННАЯ БЕЗОПАСНОСТЬ- ФАКТОР ГЕОПОЛИТИЧЕСКОЙ СТАБИЛЬНОСТИ И УСТОЙЧИВОГО РАЗВИТИЯ ГОСУДАРСТВ
}

\begin{abstract}
АннотАция: В статье исследуются актуальные вопросы в сфере продовольственной безопасности (ПБ), обеспечения качества и безопасности пищевой продукции. ПБ рассматривается как обязательное условие обеспечения реальной независимости государства сквозь призму геополитической стабильности и устойчивого развития государств. Особое внимание уделено производству и применению продукции, полученной из генно-модифицированных организмов (ГМО), их воздействию на человека и окружающую среду и политико-правовым пределам использования методов генной инженерии. Рассматривается ПБ в мире и России, проблема устойчивого отечественного производства пищевых продуктов и, как следствие, продовольственной независимости $(П Н)$ государства. Автор отмечает необходимость комплексного подхода к формированию концепции политики по цифровизации сельского хозяйства и к механизму ее реализации. Отмечены важность и значимость научного сопровождения и кадрового потенциала для эффективного решения задач, поставленных перед процессом цифровизации сельского хозяйства. На основании современных исследований изучен зарубежный опыт и целесообразность его применения для развития предпринимательства в сфере гарантирования ПБ.
\end{abstract}

КЛЮЧЕВЫЕ СЛОВА: продовольственная безопасность, Доктрина ПБ, Россия, Беларусь, Европейский союз

\section{FOOD SECURITY - A FACTOR OF GEOPOLITICAL STABILITY AND SUSTAINABLE DEVELOPMENT OF STATES}

ABSTRACT: The article examines current issues in the field of food security (FS), quality assurance and food safety. FS is considered as a prerequisite for ensuring the real independence of the state through the prism of geopolitical stability and sustainable development of States. Special 
attention is paid to the production and use of products derived from genetically modified organisms (GMOs), their impact on humans and the environment, and the political and legal limits of the use of genetic engineering methods. The article deals with FS in the world and Russia, the problem of sustainable domestic food production and, as a result, the food independence (FI) of the state. The author notes the need for a comprehensive approach to the formation of a policy concept for digitalization of agriculture and a mechanism for its implementation. The importance and significance of scientific support and human resources for the effective solution of the tasks set for the process of digitalization of agriculture were noted. Based on modern research, we have studied foreign experience and the feasibility of its application for the development of entrepreneurship in the field of guaranteeing FS.

KEYWORDS: food security, FS Doctrine, Russia, Belarus, European Union

\section{ВВЕДЕНИЕ. СТЕПЕНЬ НАУЧНОЙ РАЗРАБОТАННОСТИ ПРОБЛЕМЫ. МЕТОдОЛОГИЯ}

ПБ является составной частью национальной безопасности (НБ) государства, поэтому проблемы ее реального обеспечения являются одними из самых актуальных в современный период. В последние два десятилетия значительно возрос научный интерес в диссертационных исследованиях представителей, прежде всего, экономической ${ }^{1}$ и юридической ${ }^{2}$ наук к изучению отдельных аспектов ПБ. Рассматриваемые вопросы не только имеют важное стратегическое значение, но и являются социально значимыми для населения.

Вопросам ПБ, как на национальном, так и на международном уровне, в силу их важности, посвящено немалое количество исследований.

Зарубежные ученые У. Лиферт, М. Мазойер, Т. Мальтус, Э. Райнерт заложили общетеоретические основы и методологические принципы изучения проблем продовольственной обеспеченности. Методологический инструментарий оценки уровня ПБ изучали 3.М. Ильина, А.А. Лысоченко, Т.Ф. Рябова, И.Г. Ушачев и другие (др.) Условия и факторы реализации национальной ПБ освещали в своих работах В.Г. Гусаков, Н.В. Киреенко, С.А. Кондратенко, Г.Г. Файзуллин, А.П. Шпак, Ю.Г. Шпаковский и др. Общие вопросы обеспечения продовольствием населения отдельных государств,

\footnotetext{
1 А.В. Моисеенков, Продовольственная безопасность России как социильно-демографическая проблема (на примере сельского населения Российской Федерации): Автореф. дис. ... канд. экон. наук. М., 2002; А.А. Лысоченко, Система и механизм обеспечения продовольственной безопасности региона в условиях переходной экономики России (на примере АПК Ростовской области): Автореф. дис. ... канд. экон. наук. Ростов-на-Дону, 2002; В.В. Старостин, Совершенствование системь управления продовольственной безопасности региона: Автореф. дис. ... канд. экон. наук. Владимир, 2002, П.Н. Ломакин, Обеспечение продовольственной безопасности: внутренние и международные аспекть: Автореф. дис. ... канд. экон. наук. М., 2017 и др.

${ }^{2}$ Х.У. Белхароев, Правовое обеспечение продовольственной безопасности современной России: Автореф. дис. ... канд. юрид. наук. М., 2003; С.В. Стеценко, Становление и развитие таможенного законодательства и его роль в государственно-правовом механизме обеспечения продовольственной безопасности России в XIX - XX вв.: историко-правовое исследование: Автореф. дис. ... канд. юрид. наук. СПб., 2006; С.А. Кузнецов, Уголовно-правовая защита продовольственной безопасности: по материалам города Москвы: Автореф. дис. ... канд. юрид. наук. М., 2007; Ю.А. Валетова, Международно-правовое обеспечение продовольственной безопасности: Автореф. дис. ... канд. юрид. наук. М., 2013 и др.
} 
вопросам импортозамещения, функционирования АПК и различных аспектов выращивания/производства ГМО рассматривались в работах таких ученых, как А.П. Анисимов, А.А. Анфиногенова, С.Б. Ахметжанова, Е. А. Бубенок, Х.У. Белхароев, Г.Е. Быстров, Ю. А. Валетова, Т.Г. Виноградова, В.Н. Власенко, С.К. Девин, А.А. Кайгородцев, Л.Г. Котова, Л.Н. Крапчина, С.А. Кузнецов, В.В. Ладыченко, О.В. Лазарева, А.А. Лысоченко, С. И. Малоземов, Г. В. Маханько, Э. Михайлов, А.В. Моисеенков, Б.А. Мельников, М. Г. Порвадов, В.В. Старостин, С.В. Стеценко, Ю.С. Хромов, О.А. Чернова, и др. Вместе с тем большая часть работ посвящена отдельным аспектам проблем ПБ, тогда как, считаем, назрела необходимость комплексного исследования системы факторов, влияющих, воздействующих на ПБ, в связи с чем сохраняется необходимость дальнейшего изучения настоящей темы, осмысления накопленных знаний с точки зрения возможностей совершенствования аграрной политики и обеспечения ПБ на всех уровнях (национальном, региональном, глобальном).

\section{МЕТОдОЛОГИя}

Исследования осуществлялись с применением, в первую очередь, таких методов: абстрактно-логического, сравнительно-правового анализа, структурно-функционального, экономико-статистического.

\section{ГЕНЕЗИС МИРОВОЙ АГРОПРОДОВОЛЬСТВЕННОЙ СИСТЕМЫ}

Мир интенсивно трансформируется в условиях многовекторности развития, характеризуется перманентным проявлением разнонаправленных тенденций, факторов и угроз, сложных для мониторинга, контроля и прогнозирования. В этой связи оперативное и стратегическое выявление, квантификация и оценка потенциала влияния внешней среды является одним из направлений обеспечения устойчивости национальной ПБ 3 .

Повестка дня в сфере устойчивого развития на период до 2030 года и провозглашенное ООН Десятилетие действий по проблемам питания (2016-2025 годы) призывают все государства и все заинтересованные стороны к совместным действиям, целью которых должна стать ликвидация к 2030 году голода и неполноценного питания во всех его проявлениях. Доклад «Положение дел в области продовольственной безопасности и питания в мире - 2017» знаменует начало регулярного мониторинга достижения затрагивающих вопросы ПБ и питания целей, которые определила Повестка дня на период до 2030 года.

Интенсивный рост численности населения в условиях ограниченного производственного потенциала сельского хозяйства способствует нарастанию дефицита продовольствия и сырья. В 2016 г., после довольно кратковременного спада числа недоедающих в мире, Комитет по всемирной продовольственной безопасности $\mathrm{OOH}$

\footnotetext{
3 См.: Условия и факторы реализации Доктрины национальной продовольственной безопасности Республики Беларусь до 2030 года, В.Г. Гусаков, А.П. Шпак, Н.В. Киреенко, С.А. Кондратенко, „Вес. Нац. акад. навук Беларусі. Сер. аграр. Навук” Т. 56, №3/2018, с. 263-285.
} 
сообщил о его увеличении на 38 млн (до 815 млн чел.). Это больше, чем было в 2015 году (777 млн), хотя все еще меньше, чем в 2000 году (около 900 млн). Такое увеличение можно рассматривать, как сигнал об изменении тенденции ${ }^{4}$. В частности, положение дел в сфере ПБ ухудшилось в так называемом «поясе голода», в ряде государств Африки к югу от Сахары, Юго-Восточной и Западной Азии, причем самое заметное ухудшение ситуации имело место в зонах, затронутых конфликтами, и там, где воздействие конфликтов усугубилось засухами и наводнениями. На текущий момент очевидная остановка уменьшения числа голодающих еще не сказалась на распространении задержки детей в росте: доля таких детей сокращается, хотя в ряде регионов ситуация меняется к лучшему более низкими темпами. На глобальном уровне за период 2005-2016 годов доля детей, отстающих в росте, сократилась с 29,5 до 22,9 процента, и тем не менее все равно сегодня 155 млн проживающих по всему миру детей в возрасте до пяти лет отстают в росте от своих сверстников. От истощения в 2016 году страдали 52 млн детей в возрасте до пяти лет, то есть каждый двенадцатый ребенок на планете; больше половины из них (27,6 млн) проживают в государствах Южной Азии. Одновременно сосуществуют различные формы неполноценного питания, в некоторых государствах высокая распространенность недостаточного питания детей сочетается с высоким процентом женщин, страдающих от анемии, и высокой долей подверженного ожирению взрослого населения. Беспокойство вызывают нарастающие темпы распространения избыточного веса и ожирения. Доля детей, страдающих от ожирения и избыточной массы тела, увеличивается в большинстве регионов, доля взрослых - во всех регионах. В 2016 году 41 млн детей в возрасте до пяти лет имели избыточный вес. Увеличивается число конфликтов. Конфликты, усугубляемые климатическими потрясениями, оказывают серьезное воздействие на ПБ, именно они стали причиной большинства недавних проявлений отсутствия ПБ. Конфликты стали основной движущей силой продовольственных кризисов, они спровоцировали имевшие место в последнее время случаи возникновения голода и отсутствия достаточного питания, которые гораздо острее ощущаются там, где на фоне слабости институтов конфликты принимают затяжную форму5.

Около 2 млрд чел. страдают от недостатка питательных микроэлементов, более 600 млн чел. - от ожирения (что в современных условиях является не менее важной проблемой чем недоедание или даже голод). Число детей с избыточной массой тела и ожирением в 2016 г. увеличилось на 11 млн чел. относительно уровня 2000 г. Большинство из них проживают в развивающихся государствах - 34 млн чел. (Азии, Африке, Латинской

\footnotetext{
${ }^{4}$ N.S. Ishchenko, Cooperation of States in the sphere of quality assurance of food products, "EU Law Journal / Европейский юридический журнал” №1/2015, с. 14 - 27.

5 Положение дел в области продовольственной безопасности и питания в мире - 2017. Повьиение устойчивости к внешним воздействиям в целях обеспечения мира и продовольственной безопасности. Рим, ФАО, 2017.-133 c, http://www.fao.org/3/a-mu683r.pdf (25.01.2018).
} 
Америке и странах Карибского бассейна), а 7 млн чел. - в развитых; ухудшение социальноэкономических условий и кризисы в отдельных государствах и регионах ${ }^{6}$.

\section{ДОСТУП К ПРОДОВОЛЬСТВИЮ И РЕСУРСАМ - РЫЧАГ ВНЕШНЕПОЛИТИЧЕСКОГО ВОЗДЕЙСТВИЯ НА ГОСУДАРСТВА И НА СОЦИАЛЬНУЮ СТАБИЛЬНОСТЬ}

Рост сельскохозяйственного производства, достаточный для удовлетворения спроса, сложно обеспечить без негативного воздействия на экологическую безопасность и экосистемы; сохранение в большинстве государств различных форм неполноценного питания. Определяющее значение имеет удельный вес расходов на питание в структуре потребительских расходов. Например, жители Кении тратят почти половину располагаемых ресурсов на питание, а среднестатистическое домашнее хозяйство в США - 6,4 \%. Урбанизация населения усиливает продовольственную уязвимость. В настоящее время более половины населения мира проживает в городах и не производит сельскохозяйственную продукцию, к 2050 г. их доля составит две трети. Под влиянием указанного фактора за последнюю четверть века 27 государств перешли из категории чистых экспортеров в число импортеров продовольствия. В некоторых регионах ограничена способность обеспечивать доступность продовольствия с учетом темпов урбанизации, актуальным становится формирование политики и механизмов обеспечения ПБ городов. Не менее важным аспектом процесса является отток рабочей силы, в первую очередь квалифицированной, из сельских районов, что делает неэффективным распределение государственных инвестиций в повышение производительности и инфраструктуру между городом и деревней구 улучшение показателей в глобальном рейтинге ПБ.

\section{СТРАТЕГИЧЕСКИ ЗНАЧИМЫЕ ОТРАСЛИ В СФЕРЕ ПБ. МЕТОДЫ ОЦЕНКИ ПБ}

Пищевая промышленность в экономической системе государства по праву относится к числу стратегически значимых отраслей, поскольку наряду с сельским хозяйством формирует рынок пищевых продуктов и создает стратегические запасы продовольствия. Уровень развития пищевой промышленности является индикатором ПБ государства. Для официального определения состояния ПБ государства применяются два показателя - размер запаса зерна, который сохраняется в государстве до уборки следующего урожая,

\footnotetext{
${ }^{6}$ А.В. Антонов, Н. С. Ищенко, Г.Г. Файзуллин, Прогнозы ФАО и обеспечение продовольственной безопасности, Проблемь соииально-ориентированного инновационного развития белорусского общества и профсоюзы: материаль ХХІІІ Международной научно-практической конферениии, г. Гомель, 8 февраля 2019 г. / Гомельский филиал Международного университета «МИТСО»; под общ. ред. С.И. Ляха. - Гомель: ОДО «Центр оперативной печати», 2019. - 364 с. - С. 292 -294.

${ }^{7}$ Положение дел в области продовольственной безопасности и питания в мире, Повыпение устойчивости к внешним воздействиям в целях обеспечения мира и продовольственной безопасности, Продовольств. и с.-х. орг. Объед. Наций. - Рим: ФАО, 2017. - 117 с.; Положение дел в области продовольствия и сельского хозяйства,Использование продовольственных систем для всеобъемлющих преобразований в сельских районах / Продовольств. и с.-Х. орг. Объед. Наций. - Рим: ФАО, 2017. - 170 с.
} 
и среднедушевое производство зерновых культур. Но единой шкалы не существует, поэтому количественные характеристики показателей варьируются. Если по мнению ФАО, безопасной нормой считается так называемый переходящий запас зерна на 60 суток (17\% потребляемого зерна в государстве в течение года), то российские специалисты считают, что в государстве должен быть трехмесячный запас зерна (90 суток). Мировая практика показала, что сокращение объемов запасов ниже 17\% приводит к резкому снижению мировых цен на него, к дестабилизации мирового зернового рынка, ухудшению конъюнктуры мирового рынка для государств импортеров, дестабилизации других продуктовых рынков.

Для методов оценки ПБ государства, выделяют следующие основные критерии

- производство 75-80\% общего объема продуктов питания национальными товаропроизводителями;

- потребление населением продуктов питания с оптимальным уровнем калорийности (3000 ккал в сутки);

- обеспечение рациональной структуры питания и полное удовлетворение потребностей населения в соответствии с физиологически обоснованными нормами;

- создание восполняемого страхового запаса продовольствия на уровне не менее $17 \%$ от годового объема потребления продуктов питания;

- наличие реальной возможности удовлетворения потребности в продуктах питания, не производимых внутри государства либо производимых в недостаточных количествах, за счет импорта;

- $\quad$ производство на душу населения не менее 1 тонны зерна.

В случае превышения пороговых значений приведенных выше критериев будет обеспечено достаточное продовольственное обеспечение населения государства. Минимально необходимому уровню обеспеченности населения продуктами питания соответствует продовольственный компонент «потребительской корзины», то есть набор из 19 основных продуктов питания. При оценивании ПБ используется целый ряд показателей, то есть, проводя сравнительный анализ уровня ПБ государства необходимо использовать комплексный подход. Проведение государственного заключения ПБ предполагается на основе многомерного сравнительного анализа. Данный метод может быть применен и при оценивании регионов государства. Для проведения подобного сравнительного анализа целесообразно было бы включить следующие показатели: коэффициент ПН (самообеспеченности), уровень калорийности суточного рациона питания населения, коэффициент Саллаи (дифференциация доходов между городским и сельским населением), среднедушевое производство зерновых культур, размер среднедушевого дохода (в долларах США), процент населения, живущего за чертой бедности и не имеющего достаточного

\footnotetext{
8 Ю.С. Хромов, Проблемы продовольственной безопасности России: международные и внутренние аспекты, М.: Изд-во: «РИСИ» 2005, с.73.
} 
дохода для приобретения минимального набора продуктов питания, уровень загрузки производственных мощностей в агропромышленном секторе, изменение объемов продаж отечественных товаров. Важная роль принадлежит пищевой промышленности в обеспечении здоровья населения, являющегося одним из долгосрочных приоритетов стратегии «Агробизнес - 2020». Основой здоровья человека является, прежде всего, правильное сбалансированное питание, состоящее из доброкачественных пищевых продуктов ${ }^{9}$. В условиях рыночной экономики, наряду с безопасностью и качеством пищевых продуктов, исключительно важное значение имеет доступность их цены для низкодоходных категорий населения. Уровень жизни населения государства оказывает непосредственное влияние на рацион питания, так как формирует приоритеты в потреблении продовольствия, следствием которого является неблагоприятный фактор - снижение поступлений витаминов и белка с пищей ниже предельно допустимых норм потребления, что может привести к формированию групп населения с признаками белково-калорийной недостаточности. Состояние ПБ государства напрямую зависит от реального потребления и качества питания, достаточности отечественного производства, высокие доходы населения, невысокий объем импортируемых товаров и надежность их поставок и др. Основная цель сельскохозяйственного производства - выработка безопасных, качественных, питательных для здоровья продуктов питания в требуемых количествах, достаточном ассортименте. На рынке продаются десятки наименований пищевых продуктов зарубежного производства, содержащих компоненты, запрещенные к использованию в производстве и реализации в развитых европейских государствах. Быстрое насыщение внутреннего рынка импортными продовольственными товарами сделало продовольствие более доступным и, вместе с тем, послужило фактором подрыва национального агропромышленного производства. Основу ПБ государства, в первую очередь, создает стабильность функционирования АПК. Поэтому необходимо признать его основополагающую роль и, тем самым, необходимость государственной поддержки его стабилизации и дальнейшего развития. Продовольственное обеспечение слишком важная сторона развития общества, чтобы его полностью отдать в частные руки, а государственная поддержка может носить многоаспектный характер и, в частности, в сфере инвестирования производства. Несомненно, нужна государственная поддержка наиболее важных производств, составляющих основу ПБ государства в виде возвратных долгосрочных кредитов. В международных организациях, где неоднократно обсуждался вопрос о возможности достижения ПН от импорта, оказалось, что полной независимости ни одно из государств мира иметь не может, прежде всего, в силу природных условий. Эти условия ограничивают ассортимент и (или) количество производимых и потребляемых на месте продуктов питания.

\footnotetext{
${ }^{9}$ Н.С. Ищенко, K вопросу о правах человека в сфере здравоохранения, Актуальні проблеми медичного права: професійний погляд: матеріали Всеукраїнської науково-практичної конференції (29 листопада 2018 року, м. Київ) [Текст], Одеса 2019, с. 51 - 56.
} 
В условиях интеграции экономики государства с внешними рынками важное значение имеет повышение конкурентоспособности отечественного производства ${ }^{10}$, выпускающего продукты питания и иные товары широкого народного потребления. Важным фактором, обеспечивающим состояние ПБ, является формирование государственных резервных фондов сельскохозяйственного сырья и продовольствия, в размерах, позволяющих поддерживать устойчивое продовольственное снабжение на нормативном уровне спецпотребителей, дефицитных по производству продовольствия и подвергавшихся бедствиям регионов, а также в период резкого колебания рыночной инфраструктуры и гарантирующих выполнение экспортных поставок. Перечень и объемы фондов устанавливаются Правительством и формируются на договорной основе в местах основного товарного производства. Основу ПБ можно сформировать лишь при проведении активной государственной политики, о чем свидетельствует и опыт государств с интенсивным сельским хозяйством и развитыми рыночными отношениями, которая выражается в государственном регулировании условий воспроизводства и системной поддержке товаропроизводителей, формировании государственных страховых продовольственных фондов. Необходимость этого обусловлена рядом причин: Во-первых, если государство не в состоянии обеспечить собственным производством население продуктами питания даже по минимальным нормам, то его позиции в мире и на двухсторонних переговорах с иными государствами, по политическим, экономическим, культурным, важным социальным вопросам значительно ослабляются. Создается даже возможность оказания давления на государство в виде торгового эмбарго и ввоза продовольствия, а нередко и отказом гуманитарной помощи. Возникает реальная угроза НБ государства, проявляющаяся во всех сферах - в обороноспособности, экологической, производственно-технологической, экономической, социальной, и духовно-нравственных сферах. Обусловленность такого положения определяется приоритетным значением самой продовольственной сферы, непосредственно затрагивающей насущные интересы людей независимо от их половозрастного состояния, национальности и т.д. В сфере ПБ скрещиваются проблемы проведения агропромышленной и экономической реформы, реальные тенденции развития производства сельскохозяйственной и продовольственной продукции, отечественного рынка, степень его зависимости от мирового рынка продовольствия. Если государство ориентируется на мировой рынок, предпочитает работать с импортным поставщиком, а не с предсказуемым отечественным производителем, это подрывает устойчивость внутреннего продовольственного рынка, приводит к дестабилизации экономики, безработице сельского населения, социальной напряженности и т.д. Для производителей сельскохозяйственной продукции большое значение приобретает обеспечение стабильной реализации

\footnotetext{
${ }^{10}$ Н.С. Ищенко, А.Н. Новиков, Правовые средства защиты конкуренции в Республике Беларусь и за рубежсом, Проблемы социально-ориентированного инновационного развития белорусского общества и профсоюзы: материалы XXIII Международной научно-практической конференции, г. Гомель, 8 февраля 2019 г. / Гомельский филиал Международного университета «МИТСО»; под общ. ред. С.И. Ляха. - Гомель: ОДО «Центр оперативной печати» 2019, с. 333-334.
} 
производимой продукции, что невозможно без развитой инфраструктуры оптового продовольственного рынка. Покупатель предпочитает безопасную, качественную, доступную по цене продукцию, однако средние, а тем более мелкие предприятия не в состоянии успешно конкурировать с крупными постоянными поставщиками. Традиционная нескоординированность действий предприятий различных сфер АПК и противоречивость их интересов, с одной стороны, казалось, создают конкурентную среду, однако, с другой, отражаются на покупателе. Организация собственной переработки мяса, молока и иной продукции большинству средних хозяйств не под силу по причинам отсутствия средств и опытных кадров, определенных санитарно-гигиенических требований и налоговых условий, высоких издержек производства. Велики потери и от участия многочисленных посредников. Отсутствие у средних и малых предприятий собственной торговой сети, создание и содержание которой им недоступно, усиливает негативные последствия реформирования аграрного сектора. Необходимо учитывать ослабление экономической защищенности товаропроизводителей АПК, когда государство не регулирует цены на материально-технические ресурсы, а отрасль вынуждена противостоять действиям монополистов в сфере материально-технического снабжения и сервиса. Данную проблему не удалось решить посредством дотаций и компенсаций за счет средств республиканского и регионального бюджетов. Механизм дотирования и субсидирования носил уравнительный характер, не обеспечивал ценового и рационального использования выделяемых средств, а списание и пролонгирование долгов по кредитам некредитоспособным заемщикам создавало неравные экономические условия хозяйственной деятельности для эффективно работающих агропромышленных организаций. Россия является государством самодостаточным в своем развитии. Этот основной принцип имеет все основания быть сохраненным и в исторической перспективе. В современных условиях может сложиться уникальная и чрезвычайно благоприятная ситуация, выводящая РФ в группу мировых центров социально-экономического прогресса. Существует ряд оснований для такого утверждения. Во-первых, РФ располагает огромным земельным фондом. Во-вторых, важнейшая причина самодостаточности РФ - это его огромный природный потенциал полезных ископаемых. В-третьих, она граничит со многими известными государствами. Анализ жизненных реальностей, связанных с продовольствием, приводит к сформированному выводу о возможности практически полного фактического самообеспечения государства основными продовольственными товарами, и соответственно достижение национальной ПН и безопасности, поскольку отсутствие ряда продовольственных продуктов может компенсироваться его обменом, например, на сырье и материалы, имеющиеся в РФ. В-четвертых, РФ обладает колоссальным энергетическим потенциалом, здесь возможно использование всех имеющих практическое значение в мировой экономике видов энергоносителей, включая принципиально новые, неисчерпаемые и возобновляемые источники, чтобы обеспечить свои потребности в энергии и экспортировать их. Аграрный сектор является составной частью экономики государства, 
и без изменения ряда макроэкономических параметров она не сможет развиваться, a, следовательно, положительно влиять на решение задач пополнения бюджета государства, и, соответственно, повышения жизненного уровня населения. В развитии АПК наметились определенные позитивные тенденции, выход сельского хозяйства на устойчивую динамику роста зависит во многом от источников энергии. В-пятых, природа на земном шаре несет колоссальную антропогенную нагрузку. РФ одна из немногих государств, физически способных еще принять новые экологически чистые технологии, переход на которые позволит многократно и безболезненно для природы увеличить производственный потенциал ${ }^{11}$.

В 2019 году в РФ отмечается очень высокое качество зерна. Впервые за семь лет выявлена пшеница первого класса. Доля пшеницы третьего класса составляет практически треть от общего объема урожая. Всего пшеницы первого-четвертого классов (раньше по ГОСТу - продовольственная пшеница) - 80\% от общего сбора. На качестве зерна сказалась сухая, жаркая погода, вследствие чего протеин в пшенице рекордно вырос. Это позволяет экспортерам формировать партии с данным показателем от 13,5-14,5\% и выше. Этот факт изменил направления экспорта, например, отгрузки в Турцию увеличились в два раза в сравнении с аналогичным периодом 2018 г. Также в 2019 г. году РФ не сталкивалась с проблемой проросшего зерна, доля которого в 2018 г. доходила в отдельных регионах до $15 \%$. Тогда проблема «пророста» заметно ограничивала российских экспортеров в выборе стран назначения своих поставок.

Вместе с тем падение реальных доходов критически сказывается на структуре питания населения, т.к. большинству россиян не хватает денег до зарплаты. Недавно коллеги из РАНХиГС издали исследование о том, что политика импортозамещения привела к огромной монополизации сельскохозяйственного рынка. Сейчас на нем половину выручки генерируют агрохолдинги. Агрохолдинги - это специфически российская (да и украинская) история. Это связано с тем, что в США и ЕС принят паушальный принцип распределения дотаций - на гектар пашни, на литр молока, которые попадают и крупным, и мелким производителям. В России же крупным производителям выделяются огромные льготные кредиты. Малые предприятия к ним доступа не имеют, т.к. квота обычно уже выбрана крупными производителями. Там, где появляется монополия, там условия работы ухудшаются для крестьян. Агрохолдинги эффективны с точки зрения выпуска продукции, но село - это не только выпуск продукции, это и социальная среда.

В условиях реальных ресурсных ограничений человечество пытается использовать как традиционные, так и нетрадиционные источники энергии и сырьевых материалов, не только природные, но и техногенные ресурсы - отходы сельскохозяйственного, промышленного, строительного производства. В РФ законодательно закреплен экономический механизм

\footnotetext{
${ }^{11}$ Н.С. Ищенко, Ю.Г. Шпаковский, Обеспечение права на благоприятную окружаюшую среду в Республике Беларусь, „Вестник Московского государственного университета им. О.Е. Кугафина” (МГЮА, Российская Федерация), № 2 (30)/2017, с. 99-123.
} 
регулирования правовых отношений, при обращении с минерально-сырьевыми ресурсами и отходами, но и он далеко не совершенен. Людьми осознается объективная необходимость формирования систем хозяйственной деятельности с помощью социальных институтов и определенных правил. Принятие законодательных актов, устанавливающих стандарты, нормы, правила обращения с отходами производства и их потребление при сборе, транспортировке, удалении РФ необходимо согласовывать с государствами СНГ, EАЭС, $\mathrm{EC}^{12}$.

\section{ЦИФРОВИЗАЦИЯ - ДРАЙВЕР ИННОВАЦИОННОГО РАЗВИТИЯ ПРОРЫВНЫХ ТЕХНОЛОГИЙ РАЗВИТИЯ ОТЕЧЕСТВЕННОГО АПК}

По уровню развития технологий в сельском хозяйстве Россия занимает 15-е место в мире. А рынок информационно-компьютерных технологий в отрасли сейчас оценивается в 360 млрд руб. ${ }^{13}$ Около трети всей пищевой продукции в мире ( $\$ 940$ млрд в год) теряется или идет в отходы. Цифровизация позволит снизить эти потери и снизить число голодающих в мире людей. Объем расходов на ИКТ в сельском хозяйстве, охоте и лесном хозяйстве, по данным Росстата, в 2015 году составил 4 млрд руб., что составило 0,34 \% от всех инвестиций в ИКТ во все отрасли экономики, в 2017 году - 0,85 млрд руб., или 0,2 \%. Это самый низкий показатель для секторов, который указывает на низкую цифровизацию отечественной сельскохозяйственной экономики, но этот показатель подчеркивает, что отрасль имеет наибольший потенциал для инвестиций в технологии ИКТ. Основная доля инвестиций в ИКТ в АПК приходится на сектор производства пищевых продуктов и растениеводства ${ }^{14}$.

\section{ЗАКЛЮЧЕНИЕ/ВЫВОДЫ}

Проблема обеспечения национальной, экономической безопасности государства на основе достижения продовольственной не только и не столько аграрная, сколько

\footnotetext{
12 См.: А.П. Анисимов, О некоторых проблемах реализации концепции устойчивого развития (на примере ООПТ), Приоритетные направления развития экологического, земельного и аграрного права: материалы Респ. круглого стола / ред кол.: С. А. Балашенко [и др.], Минск: Изд. центр БГУ 2017, С. 15-18; Н. С. Ищенко, Международное сотрудничество в сфере экологии - гарантия устойчивого развития государств, Свободный порт Владивосток: проблемы применения российского законодательства. [Текст]: материалы III Международных Озёринских чтений (Владивосток, 18 декабря 2015 г.)/ под общ. ред. канд. юрид. наук, доцента А.В. Верещагиной; Владивостокский государственный университет экономики и сервиса; Институт права, Владивосток: Изд-во ВГУЭС, 2016, с. 86 - 97.

${ }_{13}$ Внедрение цифровых технологий в аграрном секторе. Роботы уходят в поле, Электронный ресурс: Аграрий - Социальная аграрная сеть, https://agrarii.com/vnedrenie-cifrovyh-tehnologij-vagrarnom-sektore-robotyuhodjat-v-pole/ (25.05.2019).

14 См.: Министерство сельского хозяйства Российской Федерации. Электронный ресурс: текст. М.: Аналитический центр Минсельхоза России, 2018, https://www.sas.com/content/dam/SAS/ ru_ru/doc/Events/ Presentation/agro-bb-2018/2-gerasimov-digitalizationof-the-agroindustrial-complex.pdf

(15.05.2019);

Пояснительная записка к предложению о реализаџии нового направления программы «цифровая экономика Российской Федераиии», Электронный ресурс: ГеоМетр Россия - Информационный портал. https://geometerrussia.ru/a213755-tsifrovoe-selskoe-hozyajstvo.html. (25.05.2019).
} 
комплексная, непосредственно связанная с конкурентоспособностью экономики государства, развитием мирового продовольственного рынка и внешнеэкономических связей. Мировому сообществу следовало бы серьёзно вмешиваться и воздействовать на производство, потребление и распределение продовольствия. Для обеспечения ПБ государства при формировании внешней и внутренней политики оптимально использовать предложенную систему, критерии и методику оценки рисков, изложенные в статье, которые в обязательном порядке должны периодически пересматриваться и могут быть использованы, в частности, при определении таможенных пошлин и квот.

В ситуации конфликта, резко ухудшающегося экологического состояния, климатической трансформации восстановление должного уровня ПБ и питания обычными способами невозможно. Необходимы подходы, ориентированные на условия конфликта и одновременно обеспечивающие оказание гуманитарной помощи, долгосрочное развитие и поддержание устойчивого мира. Построить мир в обозримом будущем, не знающий голода и неполноценного питания, будет непросто: для решения этой задачи понадобятся новые усилия и новый образ действий.

Анализируя продовольственный рынок по степени насыщенности, можно отметить, что российское производство может полностью обеспечить потребности государства в продуктах питания. Есть товары, завоз которых оправдан, так как в виду природноклиматической специфики государства, они не могут производиться на территории - кофе, фрукты и др. Продовольственные товары РФ имеют один недостаток - высокие цены относительно импортных. Между тем, российская продукция обладает большей пищевой ценностью и практически не содержит искусственных добавок и консервантов (либо содержит их меньше относительно зарубежных аналогов, завозимых в РФ). Сегодня, благодаря потребительским предпочтениям основной части населения, которая понимает полезность питания, пищевая промышленность способна развиваться. Призыв поддержать национального производителя озвучивался практически всеми Президентами СНГ.

ПБ любого государства - это проблема устойчивого отечественного производства пищевых продуктов и, как следствие, ПН государства. Безопасность связана с конструктивным решением национальной продовольственной проблемы, поступательным наращиванием производственного потенциала АПК в регионах, равномерным распределением продовольствия на территории государства. Также ПБ - это такое состояние экономики государства, при котором для каждого гражданина гарантируется физическая и экономическая доступность пищевых продуктов, соответствующих требованиям законодательства и необходимых для активного и здорового образа жизни. С одной стороны, ПБ предполагает доступность пищевых продуктов, а, с другой - их качество, питательность и безопасность, т.е. такое состояние, при котором отсутствуют недопустимый риск, связанный с причинением вреда жизни или здоровью граждан, животных и растений, 
а также окружающей среде ${ }^{15}$. Доступность пищевых продуктов возможно решить посредством методов и технологий генной инженерии. Основное преимущество продуктов, содержащих ГМО, в их цене. Они в несколько раз дешевле натуральных продуктов. Использование ГМО позволят улучшить защиту растений от болезней и вредителей и значительно увеличить урожайность сельскохозяйственных культур. В настоящее время технология получения ГМО несовершенна, поэтому трудно дать точный прогноз, в каком направлении произойдут эти изменения организма. Исходя из этого, можно утверждать, что любой трансгенный продукт потенциально опасен для здоровья человека из-за возможных рисков: нарушение обмена веществ; появление желудочной микрофлоры, стойкой к антибиотикам; аллергические и онкологические заболевания; канцерогенный и мутагенный эффекты. Очевидно, что процессы производства, переработки, реализации и использования продуктов, содержащих ГМО должны соответственно законодательно регулироваться государством после проведения серьезных исследований, в результате которых необходимо получить ответы на жизненно важные вопросы: 1) токсична ли ГМпища для системы органов при пролонгированном воздействии; 2) вызывает ли она тяжкие, например, онкологические заболевания и врожденные дефекты; 3) влияет ли негативно на репродуктивную способность. Только опираясь на результаты полноценных всесторонних исследований последствий использования ГМО можно сделать вывод о степени опасности применения методов генной инженерии в обеспечении, как в России, так и во всем мире ${ }^{16}$.

Россия всегда держалась на хлебе, а его отсутствие, в силу неурожаев, а чаще войн и внутренних катаклизмов, вызывали бунты и голод. Стратегический запас, который сейчас находится в ведении «Госрезерва», обязан быть полон. Излишки можно продавать. И это уже инструмент экономического и, как вытекающая составляющая, политического влияния в мировой политике. Возникла необходимость более активного государственно-частного партнерства при реализации программ, мониторинга.

Выполненный анализ позволяет сделать некоторые выводы о влиянии тенденций мирового рынка на устойчивость национального агропродовольственного комплекса и обеспечение ПБ: все более широкое применение конкурентами на внутреннем и внешнем агропродовольственных рынках протекционистских мер, включая увеличение государственной поддержки национальных товаропроизводителей и применение регуляторов конкурентной среды; более активное наращивание конкурентных преимуществ и инновационного потенциала в чувствительных отраслях АПК со стороны партнеров по ЕАЭС и ЕС; возрастающие требования к качеству пищевых продуктов на мировом рынке и рынке ЕАЭС, которые определяют эффективность экспорта российской продукции;

15 См.: Об утверждении Доктрины продовольственной безопасности Российской Федерации: Указ Президента РФ от 30 января 2010 г. № 120, СЗ РФ, №. 5/2010, СТ. 502.

16 О санитарно-эпидемиологическом благополучии населения: Федеральный закон от 30 марта 1999 г, № 52Ф3 (ред. от 29.12.2014), СЗ РФ. 1994. № 14. Ст. 1650; 2014. № 26 (ч. 1). Ст. 3377; 2015. № 10. Ст. 1418;

$O$ внесении изменений в отдельные законодательные акты Российской Федерации в части совершенствования государственного регулирования в области генно-инженерной деятельности: Законопроект № 714809-6 // http://www.asozd2.duma.gov.ru (12.05.2015). 
усиление влияния конъюнктуры мирового рынка на устойчивость национального агропродовольственного рынка и эффективность национальных товаропроизводителей; концентрация и монополизация экспорта продовольствия отдельными государствами и усиление их доминирования на мировом рынке и др.

Кроме того, для обеспечения ПБ необходимо: государства должны действовать сообща, чтобы справиться с общими вызовами; увеличить емкость рынка органического сельского хозяйства; реализовать Глобальную программу ответственности инвестиций в сельское хозяйство и продовольственные системы, т.к. инвестиции являются решающим фактором укрепления ПБ и конкуренции на внешних рынках; усилить ведущую роль государства в инновационном и инвестиционном процессе и создании благоприятных условий; рост государственной поддержки в абсолютном выражении и относительно валовой добавленной стоимости, созданной в сельском хозяйстве.

Таким образом, анализ рассмотренных тенденций позволяет определить, что задачи в сфере обеспечения ПБ и устойчивого развития сельского хозяйства на перспективу требуют принципиально новых решений, которые обозначены и предложены в Доктрине. Необходим комплексный подход к формированию концепции политики по цифровизации сельского хозяйства и к механизму по ее реализации. Важно научное сопровождение и кадровый потенциал для эффективного решения задач, поставленных перед процессом цифровизации сельского хозяйства и гарантированием ПБ. Ключевые направления и меры по укреплению национальной ПБ сосредоточены в следующих сферах: повышение устойчивости производства сельскохозяйственной продукции, сырья и продовольствия; повышение экономической доступности продуктов питания для всех групп населения; регулирование ПБ; повышение конкурентоспособности производства и сбыта продукции; кооперация и интеграции в агропродовольственной сфере; развитие научно-инновационного потенциала.

Особенно сложным в современных условиях, в условиях пандемии коронавируса, становится гарантирование ПБ. По заявлениям ООН не стихающая пандемия коронавируса на планете может привести уже в ближайшем будущем к серьезным проблемам с продовольствием. Так, исполнительный директор Всемирной продовольственной программы (ВПП) ООН Д. Бизли заявил, что через несколько месяцев человечество может столкнуться с голодом библейского масштаба, если вовремя не будут предприняты меры по обеспечению ПБ стран ${ }^{17}$. В связи с этим сегодня как никогда необходимо консолидировать усилия всех государств, дабы справиться с ситуацией. 17 В ООН предупредили о голоде библейского маситаба, если не остановить коронавирус, https://strana.ua/
news/262825-v-oon-predupredili-o-holode-biblejskoho-masshtaba-esli-ne-ostanovit-koronavirus.html (22.04. 2020). 


\section{ЛИТЕРАТУРА}

Antoine Louis. 2010. Vote on ending zero tolerance postponed. Europolitics. 10 February.

From uniformity to diversity: a paradigm shift from industrial agriculture to diversified agroecological systems. IPES FOOD In http://www.ipes-food.org/images/Reports/ UniformityToDiversity_FullReport.pdf].

The Global Food Security Index. 2018. Рим: ФАО [The Global Food Security Index. 2018. Rim: FAO]. http://www.fao.org/3/a-mu683r.pdf.

Ishchenko Nina Sergiejevna. 2015. Cooperation of States in the sphere of quality assurance of food products. EU Law Journal (Европейский юридический журнал / Evopejskij juridicheskj zhurnal) №1: $14-27$.

Nutrition and food systems: a report by the high level panel of experts on food security and nutrition. 2017. FAO CFS Committee on World Food Security. - Rome: HLPE In http://www.fao.org/ fileadmin/user_upload/hlpe/hlpe_documents/HLPE_Reports/HLPE -Report-12_EN.pdf.

Scott Allison H. 2015. "Genetically Modified Crop Regulation: The Fraying of America's Patchwork Farm Lands". Villanova Environmental Law Journal Vol. 26: 149-150.

Yu Wenxuan, Wang Canfa. 2012. "Agro-GMO Biosafety Legislation in China: Current Situation, Challenges, and Solutions”. Vermont Journal of Environmental Law 13.

Алтухов Анатолий Иванович. 2016. „Возможные риски и угрозы национальной продовольственной безопасности и независимости”. АПК: экономика, упр 5: 4-16 [Altukhov Anatolij Ivanovich. 2016. „Vozmozhnyje riski i ugrozy nasional'noj prodovol'stvennoj bezopasnosti i nezavisimosti'. APK: ekonomika, upr 5: 4-16].

Анисимов Алексей Павлович, Попова Ольга Владимировна. 2017. „Правовое регулирование использования ГМО в сельском хозяйстве: дискуссионные вопросы”. Вестник Балтийского федерального университета им. И. Канта. Сер.: Гуманитарные и общественные науки 3: 21-29 [Anisimov Aleksiej Pavlovich, Popova Ol'ga Vladimirovna. 2017. „Pravovoe regulirovanije ispol'zovanija GMO v sel'skom hozjajstve: diskussionnyje voprosy. Vestnik Bal'tijsko federal'nego universiteta im. I. Kanta. Ser.”. Gumanitarnyje i obshchestvennyje nauki 3: 21-29].

Анисимов Алексей Павлович. 2017. О некоторых проблемах реализации концепции устойчивого развития (на примере ООПТ) В Приоритетные направления развития экологического, земельного и аграрного права: материалы Респ. круглого стола/ ред кол.: Сергей Александрович Балашенко [и др.], 15-1. Минск: Изд. центр БГУ [Anisimov Aleksiej Pavlovich. 2017. O nekotoroykh problemach realizatsii kontseptsii ustojchivogo razvitija (na primere OOPT) V Priorytetnyje napravlenija razvitija ekologicheskogo, zemel'nogo i agrarnego prava: materialy Resp. Kruglogo stola. red. kol. Siergiej Aleksandrovich Balashenko (i drugije), 15-1. Minsk: Izd. tsentr. BGU].

Антонов Антон В., Ищенко Нина Сергеевна. Файзуллин Файзуллин Гаяз Габделисламович. 2019. Прогнозы ФАО и обеспечение продовольственной безопасности V Проблемы социально-ориентированного инновационного развития белорусского общества и профсоюзы: материалы XXIII Международной научно-практической конференции, г. Гомель, 8 февраля. Гомельский филиал Международного университета «МИТСО»; ред. Лях С.И, 292-294. Гомель: ОДО «Центр оперативной печати»[Antonov Anton V. Ishchenko Nina Siergiejevna, 
Fajzulin Gajaz Gabdelislamovich. 2019. Prognozy FAO i obecpechenije prodovol'stvennoj bezopasnosti V Problemy sotsial'no-orientirovannogo razvitija belorusskogo obshchestva i profsojuzy: materialy XXIII Mezhdunarodnoj nauchnoprakticheskoj konferenstii, g. Gomel', 8 fevralja. Gomel'skij filial' Mezhdunarodnogo universiteta „MITSO”, red. Siergiej Iosifovivh Ljakh, 292-294. Gomel': ODO „Tsentr operativnoj pechati'].

Белхароев Хаджимурад Уматгиреевич. 2003. Правовое обеспечение продовольственной безопасности современной России: Автореф. дис. ... канд. юрид. наук. M [Belkharoev Khadzhimurad Umatgireevich. 2003. Pravovoe obespechenije prodovol'stvenooj bezopasnosti sovremennoj Rossi: Avtoref. dis. ...kand. Jurij. nauk. M].

Бобылев Сергей Николаевич, Григорьев Леонид Маркович (ред.). 2018. Человек и инновации: доклад о человеческом развитии в Российской Федерации за 2018. M.: Аналитический центр при Правительстве Российской Федерации [Bobyliev Sergiej Nikolaevich, Grigor'iev Leonid Markovich (red.). 2018. Chelovek i innovatsii: doklad o chelovecheskom razvitii v Rossijskoj Federatsii za 2018 g. M: Analiticheskij tsentr pri Pravitel'stve Rossijskoj Federatsii].

В ООН предупредили о голоде библейского масштаба, если не остановить коронавирус [V OON predupredili o golode biblejskogo mashtaba, jeśli Ne ostanovit' koronavirus] https://strana.ua/news/262825-v-oon-predupredili-o-holode-biblejskoho-masshtaba-esline-ostanovit-koronavirus.html.

Валетова Юлия Александровна. 2013. Международно-правовое обеспечение продовольственной безопасности: Автореф. дис. ... канд. юрид. наук. М. [Valetova Julija Aleksandrovna. 2013. Mezhdunarodno-pravovoe obespechenije prodovol'stvennoj bezopasnosti: Avtoref. dis. ... kand. jurid. nauk. M.].

Внедрение цифровых технологий в аграрном секторе. Роботы уходят в поле. Электронный ресурс: Аграрий. Социальная аграрная сеть. [Vnedrenije tsifrovykh technologii v agrarnom sektore. Roboty uhodjat v pole. Elektronnyj resurs: Agrarnij. Sotsijal'naja agrarna ja set']. https://agrarii.com/vnedrenie-cifrovyh-tehnologijvagrarnom-sektore-roboty-uhodjat-v-pole/.

Гусаков Владимир Григорьевич [и др.]. 2016. Продовольственная безопасность Республики Беларусь в условиях функционирования Евразийского экономического союза. Мониторинг - 2015: в 2 ч. Ин-т систем. исслед. в АПК Нац. акад. наук Беларуси. Минск: Ин-т систем. исслед. в АПК НАН Беларуси [Gusakov Vladimir Grigor'evich [i dr.]. 2016. Prodovol'stvennaja bezopasnost' Respubliki Belarus' v usolvijakh funktsionirovanija Evrazijskogo ekonomicheskogo sojuza. Monitoring - 2015: v 2 c. In-t sistem. issied. V APK Nats. akad. nauk Belarusi. Minsk: In-t sistem. issledov. V APK NAN Belarusi].

Гусаков Владимир Григорьевич [и др.]. 2017. Основные достижения, тенденции и перспективы развития национальной продовольственной безопасности. Вклад аграрной экономической науки в обеспечение продовольственной безопасности страны: материалы круглого стола, Минск, 28 сент. / Ин-т систем. исслед. в АПК НАН Беларуси. - Минск [Gusakov Vladimir Grigor'evich (i dr.). 2017. Osnovnyje dostizhenija, tendentsii i perspektivy razvitija natsional'noj prodovol'stvennoj bezopasnosti. Vklad agragnoj ekonomicheskoj nauki $\mathrm{v}$ obespechenije prodovol'stvennoj bezopasnosti 
strany: materialy kruglogo stola, Minsk, 28 sent.. / In-T sistem. issled. V APK PAN Belarusi-Minsk].

Гусаков Владимир Григорьевич [и др.]. 2017. Продовольственная безопасность Республики Беларусь. Мониторинг - 2016: социально-экономические аспекты. Ин-т систем. исслед. В АПК Нац. акад. наук Беларуси. - Минск: Ин-т систем. исслед. в АПК НАН Беларуси [Gusakov Vladimir Grigor'evich [i dr.]. 2017. Prodovol'stvennaja bezopasnost' Respubliki Belarus'. Monitoring - 2016: sotsijal'noekonomicheskije aspekty. In-t sistem. issled. V APK nats. akad. nauk Belarusi. Minsk: In-sistem. issled. V APK NAN Belarusi].

Гусаков Владимир Григорьевич. 2018. Условия и факторы реализации Доктрины национальной продовольственной безопасности Республики Беларусь до 2030 года. Вес. Нац. акад. навук Беларусі. Сер. аграр. навук 56(3): 263-285 [Gusakov Vladimir Grigor'evich. 2018. Uslovija i faktory realizatsii Doktriny natsional'noj prodovol'stvennoj bezopasnosti Respubliki Belarus' do 2030 goda. Ves. Nats. Akad. Nauk Belarusi. Ser. Agrar. Nauk 56(3): 263-285].

Девин Сергей Константинович. 2010. „О ходе реализации Федерального закона «О развитии сельского хозяйства»”. Экономика сельскохозяйственных и перерабатывающих предприятий 7. [Devin Siergiej Konstantinovich. 2010. „O khode realizatsii Federal'nogo zakona 'O razvitii sel'skogo hozjajstva' ”. Ekonomika selskokhozjajstvennykh i pererabatyvajushchikh predprijatij 7].

Декларация Всемирного саммита по продовольственной безопасности, Рим, 16.11.2009. [Deklaratsija Vsemirnogo sammita po prodovol'stvennoj bezopasnostti, Rim, 16.11.2009] URL: www.mid.ru.

Ищенко Нина Сергеевна, Власенко Валерий Николаевич. 2016. Экология и обеспечение продовольственной безопасности В Верховенство права и правовое государство: проблемы теории и практики. международ. научно-практич. конф. (РГУП/ Российский Государственный Университет Правосудия, Москва, 13-16 апреля 2015г.), 451-460. Сб. научных статей. М.: Российский Государственный Университет Правосудия [Ishchenko Nina Siergiejevna, Vlasenko Valerij Nikolaevich. 2016. Ekologija i obespechenije prodovol'stvennoj bezopasnosti V Verkhovenstvo prava i pravovoe gosudartsvo: problemy teorii i praktyki. Mezhdunarodn. Nauch.-praktich. Konf. (RGUP/Rossijskij Gosudarstvennyj Universitet Pravosudija, Moskva, 13-16 aprelja 2015 g.), 451-460. Sb. Nauchnykh statej, M.: Rossijskij Gosudarstvennyj Universitet Pravosudija].

Ищенко Нина Сергеевна, Глушакова Я. И. 2019. Римские принципы устойчивой глобальной продовольственной безопасности В Проблемы социально-ориентированного инновационного развития белорусского общества и профсоюзы: материалы XXIII Международной научно-практической конференции, г. Гомель, 8 февраля 2019 г. / Гомельский филиал Международного университета «МИТСО»; ред. Лях С. И., 307311. Гомель: ОДО «Центр оперативной печати» [Ischenko Nina Siergiejevna, Glushakova J. I. 2019. Rimskije printsipy ustojchivoj global'noj prodovol'stvennoj bezopasnosti V Problemy sotsial'no-orientirovannogo razvitija belorusskogo obshchestva i profsojuzy: materialy XXIII Mezhdunarodnoj nauchno-prakticheskoj konferenstii, g. Gomel', 8 fevralja 2019 g. Gomel'skij filial' Mezhdunarodnogo universiteta „MITSO”, red. Siergiej Iosifovivh Ljakh, 307-311. Gomel': ODO „Tsentr operativnoj pechati”]. 
Ищенко Нина Сергеевна, Новиков, А. Н. 2019. Правовые средства защиты конкуренции в Республике Беларусь и за рубежом В Проблемы социально-ориентированного инновационного развития белорусского общества и профсоюзы: материалы XXIII Международной научно-практической конференции, г. Гомель, 8 февраля 2019 г. Гомельский филиал Международного университета «МИТСО». ред. С.И. Лях, 333334. Гомель: ОДО «Центр оперативной печати» [Ischenko Nina Siergiejevna, Novikov A.N. 2019. Pravovyje sredstva zashchity konkurentsii v Respublike Belarus' i za rubezhom V Problemy sotsial'no-orientirovannogo razvitija belorusskogo obshchestva i profsojuzy: materialy XXIII Mezhdunarodnoj nauchno-prakticheskoj konferenstii, g. Gomel', 8 fevralja 2019 g. Gomel'skij filial' Mezhdunarodnogo universiteta „MITSO”, red. Siergiej Iosifovivh Ljakh, 333-334. Gomel': ODO „Tsentr operativnoj pechati”].

Ищенко Нина Сергеевна, Файзуллин Гаяз Габделисламович. 2019. К вопросу о продовольственной безопасности В Право и современная экономика: новые вызовы и перспективы. Сборник материалов II научно-практической конференции с международным участием юридического факультета СПбГЭУ. 9 апреля. ред. Крайновая Надежда Александровна, 37-45. СПб.: Изд-во СПбГЭУ [Ischenko Nina Siergiejevna, Fajzullin Gajaz Gabdelislamovich. 2019. K voprosu o prodovol'stvennoj bezopasnosti V Pravo i sovremennaja ekonomika: novyje vyzovy i perspektivy. Sbornik materialov II nauchno-prakticheskoj konferentsii s mezhdunarodnym uchastiem juridisherkogo fakul'teta SPbGEU. 9 aprelja. red. Krajnovaja Nadezhda Aleksandrovna, 37-45. SPb.: Izd-vo SPbGEU].

Ищенко Нина Сергеевна, Шпаковский Юрий Григорьевич. 2017. Обеспечение права на благоприятную окружающую среду в Республике Беларусь. Вестник Московского государственного университета им. О.Е. Кутафина (МГЮА, Российская Федерация). 2(30): 99-123 [Ishczenko Nina Siergieevna, Szpakovskij Jurij Grigor'evich. 2017. Obespechenije prava na blagoprijatnuju okruzhajushczuju credu v Respublike Belarus'. Vestnik Moskovskoo gosudarstvennogo universiteta im. O.E. Kutafina (MGJUA, Rossijskaja Federatsija) 2(30): 99- 123].

Ищенко Нина Сергеевна, Шпаковский Юрий Григорьевич. 2019. Агропродовольственная торговая политика в постсоветских государствах В Проблемы социальноориентированного инновационного развития белорусского общества и профсоюзы: материалы XXIII Международной научно-практической конференции, г. Гомель, 8 февраля. Гомельский филиал Международного университета «МИТСО»; под общ. ред. Сергей Иосифович Лях. Гомель: ОДО «Центр оперативной печати», 298-302 [Ishczenko Nina Siergieevna, Szpakovskij Jurij Grigor'evich. 2019 Agroprdovol'stvennaja torgovaja politika $\mathrm{V}$ postsovetskikh gosudarstvakh. V Problemy sotsial'noorierntirovannogo innovatsionnogo razvitija belorusskogo obshchestva i profsjojuzy: materialy XXIII Mezhdunarodnoj nauchno-prakticheskoj konferentsii, g. Gomel', 8 fevralja. Gomel'skij filial Mezhdunarodnogo universiteta „MITTSO”, red. Siergiej Iosifovivh Ljakh. Gomel': ODO „Tsentr operativnoj pechati”, 298-302].

Ищенко Нина Сергеевна. 2016. Международное сотрудничество в сфере экологии гарантия устойчивого развития государств В Свободный порт Владивосток: проблемы применения российского законодательства: [Текст]: материалы III Международных Озёринских чтений (Владивосток, 18 декабря 2015 г.). ред. Верещагина Алла Васильевна, 86-97. Владивостокский государственный 
университет экономики и сервиса. Институт права. Владивосток: Изд-во ВГУЭС [Ishczenko Nina Siergiejevna. 2016. Mezhdunarodnoje sotrudnichestvo v sfere ekologii garantija ustojchigo razvitija gosudarstv V Svobodnyj port Vladivostok: problemy primenenija rossijskogo zakondatel'stva: [Tekst:] materialy III Mezhdunarodnykh Ozjorinskikh chtenij (Vladivostok, 18 dekabrja 2015 g.). red. Veregashchina Alla Vasil'evna, 86-97. Vladivostotskij gosudarstvennyj universitet ekonomiki i ser visa. Institut prava. Vladivostok: Izd-vo VGUES].

Ищенко Нина Сергеевна. 2019. К вопросу о правах человека в сфере здравоохранения. Актуальні проблеми медичного права: професійний погляд: матеріали Всеукраїнської науково-практичної конференції (29 листопада 2018 року, м. Київ) [Текст], 51 - 56. Одеса: Фенікс [Ishchenko Nina Siergiejevna. 2019. K voprosu o pravakh cheloveka v sfere zdravokhranenija. Aktualnyi problemy medichnogo prava: profesijnyj pogljad: mareriali Vseukrainskoj naukowo-praktichnoj konferentsii (29 listopada 2018 roku, m. Kyiv) [Tekst], 51-56. Odesa: Feniks].

Казембаев М. Е. 1997. „Как обеспечить продовольственную безопасность?”. Экономика Казахстана. № 11-12 [Kazambaev M. E. 1997. „Kak obespechit’ prodovol’stvennuju bezopasnost". Ekonomika Kazakhstana 11-12].

Кешелава Амиран Варламович, Буданов Владимир Григорьевич, Румянцев Владимир Юрьевич и др. ред. Кешелава Амиран Варламович, гл. «цифр.» конс. Зимненко Игорь Анатольевич. 2017. Введение в «Цифровую» экономику. М.: ВНИИГеосистем [Keshelava Amiran Varlamovich, Budanov Vladimir Grigorievich, Rumjantsev Vladimir Juri'evich i dr. red. Keshelava Amiran Varlamovich, g. „tsifr.” kons. Zimnenko Igor’ Anatol'evich. 2017. Vvedenije v „Tsifrovuju” ekonomiku. M.: VNIIGeoisistem].

Климова Наталья Владимировна. 2011. Продовольственная безопасность в обеспечении конкурентоспособности страны. [Klimova Natal'ja Vladimirovna. 2011. Prodovol'stvennaja bezopasnost' v obespechenii konkurentosposobnosti strany] httpJ/econf.rae.ru/sci ence/6.

Крылатых Эльмира Николаевна. 2011. Обеспечение продовольственной безопасности России и мира: возможности, риски, угрозы. М.: ГНУ ВИАПИ [Krylatykh El'mira Nikolaevna. 2011. Obespechenije prodovol'stvennoj bezopasnosti Rossii i mira: vozmozhnosti, riski, ugrozy. M.: GNU VIAPI].

Кузнецов Сергей Александрович. 2007. Уголовно-правовая защита продовольственной безопасности: по материалам города Москвы: Автореф. дис. ... канд. юрид. наук. М. [Kuznetsov Sergiej Aleksandrovich. 2007. Ugolovno-pravovaja zashchita prodovol'stvennoj bezopasnosti: po materialam goroda Moskvy: Avtoref. dis. ... kand. jurid. nauk. M.].

Ломакин В.И. 2011. Мировая и национальная продовольственная безопасность, М.: Экономика [Lomakin V.I. 2011. Mirovaja i natsional'naja prodovol'stvennaja bezopasnost'. M.: Ekonomika].

Ломакин Петр Николаевич. 2017. Обеспечение продовольственной безопасности: внутренние и международные аспекты: Автореф. дис. ... канд. экон. наук. М. [Lomakin Pjotr Nikolaevich. 2017. Obespechenije prodovol'stvennoj bezopasnosti: vnutrennije i mezhdunarodnyje aspekty: Avtoref. dis. ... kand. ekon. Nauk. M.].

Лысоченко Алла Алексеевна. 2002. Система и механизм обеспечения продовольственной безопасности региона в условиях переходной экономики России (на примере АПК 
Ростовской области): Автореф. дис. ... канд. экон. наук. Ростов-на-Дону [Lysochenko Alla Aleksiejevna. 2002. Sistema i mekhanizm obespechenija prodovol'stvennoj bezopasnosti regiona $\mathrm{v}$ uslovijakh perekhodnoj ekonomiki Rossii (na primere APK Rostovskoj oblasti): Avtoref. dis. ... kand. ekonom. nauk. Rostov-na-Donu].

Менив Олексій Ігорович. 2016. Правовое обеспечение использования ГМО при выращивании сельскохозяйственной продукции растительного происхождения в Украине и ЕС: автореф. дис. ... канд. юр. наук. Харьков [Meniv Oleksij Igorovich. 2016. Pravovoje obespechenije ispol'zovanija GMO pri vyrashchivanii sel'skohozjajstvennoj produktsii rastitel'nogo proiskhozdhenija v Ukraine i EC: avtoref. dis. ... kand. jur. nauk. Kharkov].

Моисеенков Андрей Валентинович. 2002. Продовольственная безопасность России как социально-демографическая проблема (на примере сельского населения Российской Федерации): Автореф. дис. ... канд. экон. наук. М. [Moiseenkov Andrej Valentinovich. 2002. Prodovol'stvennaja bezopasnost' Rossii kak sotsial'no-demograficheskaja problema (na primere sel'skogo naselenija Rossijskoj Federatsii): Avtoref. dis. .. kand. ekon. Nauk. M.].

O внесении изменений в отдельные законодательные акты Российской Федерации в части совершенствования государственного регулирования в области генно-инженерной деятельности: Законопроект 714809-6. [О vnesenii izmenenij v otde'lnyje zakondatel'nyje akty Rossijskoj Federatsii v chasti covershenstvovanija gosudarstvennogo regulirovanija v oblasti genno-inzhenernoj dejatel'nosti: Zakonoprojekt 714809-6]. http://www.asozd2.duma.gov.ru.

О санитарно-эпидемиологическом благополучии населения: Федеральный закон от 30 марта 1999 г. № 52-Ф3 (ред. от 29.12.2014). С3 РФ. 1994. № 14. Ст. 1650; 2014. № 26 (ч. 1). Ст. 3377. 2015. № 10. Ст. 1418 [O sanitarno-epidemiologicheskom blagopoluchi naselenija: Federal'nyj zakon ot 30 marta 199 g. № 52-FZ (red. ot 29.12.2014). SZ RF. 1994. № 14. St. 1650; 2014. № 26 (ch. 1). St. 3377. 2015 № 10. St. 1418].

О техническом регулировании: Федеральный закон от 27 декабря 2002 г. № 184-Ф3 (ред. от 23.06.2014). СЗ РФ. 2002. № 52 (ч. 1). Ст. 5140; О государственном регулировании в области генно-инженерной деятельности: Федеральный закон от 5 июля 1996 г. № 86-Ф3 (ред. от 19.07.11). С3 РФ. 1996. № 28. Ст. 3348; 2011. № 301 (ч. 1). Ст. 4596 [O tekhnicheskom regulirovanii: Federal'nyj zakon ot 27 dekabrja 2002 g. № 184-FZ (red. ot 23.06.2014). SZ RF. 2002. № 52 (ч. 1). Ст. 5140; O gosudarstvennom regulirovanii v oblasti genno-inzhenernoj dejatel'nosti: Federal'nyj zakon ot 5 ijulja 1996 g. № 86-FZ].

Об утверждении Доктрины продовольственной безопасности Российской Федерации: Указ Президента РФ от 30 января 2010 г. № 120. С3 РФ. 2010. №. 5. Ст. 502 [Ob. Utverzhdenii Doktriny prodovol'stvennoj bezopasnosti Rossijskoj Federatsii: Ukaz Prezidenta RF ot 30 janvarja 2010 g. № 120. SZ RF. 2010. №. 5. St. 502].

Паркер Джеффри, Vан Альстин Маршалл, Чаудари Санджит. 2017. Революция платформ. Как сетевые рынки меняют экономику - и как заставить их работать на вас. М. [Parker Dzheffri, Van Al'stin Marshall, Chaudari Sandzhit. 2017. Revolutsija platform. Kak setjovyje rynki menjajut ekonomiku - i kak zastavit' ikh rabotat' na vas. M.].

Положение дел в области продовольственной безопасности и питания в мире - 2017. Повышение устойчивости к внешним воздействиям в целях обеспечения мира и продовольственной безопасности. Рим, ФАО. [Polozhenije del v oblasti prodovol'stvennoj bezopasnosti i pitanija v mire - 2017. Povyshenije ustojchivosti 
k vneshnim vozdejstvijam v tseljakh obespechenija mira i prodovol'stvennoj bezopasnosti. Rim, FAO] http://www.fao.org/3/a-mu683r.pdf.

Пояснительная записка к предложению о реализации нового направления программы «цифровая экономика Российской Федерации». Электронный ресурс: ГеоМетр Россия - Информационный портал. [Pojasnitel'naja zapiska k predlozheniju o realizatsii novogo napravlenija programy ,tsigrovaja ekonomika Rossijskoj Federatsii”. Elektronnyj resurs: GeoMetr Rossija - Informatsionnyj portal]. https://geometer-russia.ru/a213755tsifrovoe-selskoe-hozyajstvo. html.

Сафин Урал Закуанович. 2008. „Вопросы обеспечения продовольственной безопасности России”. Вестник Академии экономической безопасности МВД России 2 [Safin Ural Zakuanovich. 2008. „Voprosy obespechenija prodovol'stvennoj bezopasnosti Rossi”. Vestnik Akademii ekonomicheskoj bezopasnosti MVD Rossi 2].

Соколова Наталья Александровна. 2010. Международно-правовые аспекты управления в сфере охраны окружающей среды: дис. ... д-ра юр. наук. M. [Sokolova Natal'ja Aleksandrovna. 2010. Mezhdunarodno-pravovyje aspekty upravlenija v sfere okhrany okruzhajushchej sredy: disc. d-ra. jur. Nauk. M.].

Старостин Владимир Викторович. 2002. Совершенствование системы управления продовольственной безопасности региона: Автореф. дис. ... канд. экон. наук. Владимир [Starostin Vladimir Vitorovich. 2020. Sovershenstvovanije systemy upravlenija prodovol'stvennoj bezopasnosti regiona: Avtoref. dis. ... . kand. ekonom. Nauk. Vladimir].

Стеценко Светлана Владимировна. 2006. Становление и развитие таможенного законодательства и его роль в государственно-правовом механизме обеспечения продовольственной безопасности России в XIX - XX вв.: историко-правовое исследование: Автореф. дис. ... канд. юрид. наук. СПб. [Stetsenko Svetlana Vladimirovna. 2006. Stanovlenije i razvitije tamozhennogo zakondatel'stva i jego rol' v gosudarstvennopravovom mekhanizme obespechenija prodovol'stvennoj bezopasnosti Rossii c XIX-XX vv.: istoriko - pavovoe issledovanije: Avtoref. dis. ... kand. jurid. nauk. $\mathrm{CPb}$.

Ушачев Иван Григорьевич [и др.]. 2015. „Доктрина продовольственной безопасности Российской Федерации нуждается в совершенствовании”. АПК: экономика, упр. 9: 312 [Ushachev Ivan Grigorievich (i drug.). 2015. „Doktrina prodovol'stvennoj bezopasnosti Rossijskoj Federatsii nuzhdaetsja v sovershenstvovanii”. APK: ekonomika, upr 9: 3-12].

Хромов Юрий Сеергеевич. 2005. Проблемы продовольственной безопасности России: международные и внутренние аспекты. М.: Изд-во: «РИСИ» [Khromov Jurij Siergeevich. 2005. Problemy prodovol'tstvennoj bezopasnosti Rossi: mezhdunarodnyje i vnutrennije aspekty. M.: Izd-bo: „RISI’].

Цветков Валерий Анатольевич и др. 2018. „Цифровая экономика и цифровые технологии как вектор стратегического развития национального агропромышленного сектора". Вестник московского университета № 6. Экономика № 1.: 45-64 [Tsvetkov Valeriij Anatol'evich i dr. 2018. „Tsifrovaja ekonomika i tsifrovyje technologii kak vektor strategicheskogo razvitija nasional'nogo agropromyshlennogo sektora". Vestnik moskovskogo universiteta № 6. Экономика № 1.: 45-64].

Чернова Ольга Анатолевна, Степенко Валерий Ефремович. 2006. „Продовольственная безопасность: научно-теоретические подходы к определению терминологии". Юридический мир 10.: 44 [Chernova Ol'ga Anatolevna, Stepenko Valerij Efremovich. 
2006. „Prodovol'stvennaja bezopasnost': nauchno-teoreticheskije podchody k opredeleniuju terminologii”. Juridicheskij mir 10.: 44].

Чуйко Наталия Андреевна. 2011. „Основные подходы к регулированию генетически модифицированных организмов в международной практике". Сибирский юридический вестник 1(52): 160-165 [Chujko Natalija Andreevna. 2011. „Osnovnyje podhody k regulirovaniju geneticheski modifitsirovannykh organizmom v mezhdunarodnoj Praktiker". Sibirskij juridicheskij vestnik 1(52): 160-165].

Шарова Галина Николаевна. 2004. „Защита от некачественной продукции.” «Черные дыры» в российском законодательстве 3.: 144-146 [Sharova Galina Nikolaevna. 2004. „Zashchita ot nekachestvennoj produktsii”. „Chernyje dyry” v rossijskom zakondatel'stve 3: 144-146].

Шпак Александр Петрович [и др.]. 2017. Основные положения Доктрины продовольственной безопасности Республики Беларусь. Аграр. экономика 3: 2-14 [Shpak Aleksandr Petrovich (i dr.). 2017. Osnovnyje polozhenija Doktriny prodovol'stvennoj bezopasnosti Respubliki Belarus' Agrag. ekonomika. 3: 2-14].

Шпак Александр Петрович, Киреенко Наталья Владимировна, Кондратенко Светлана Александровна. 2017. Стратегия и механизмы обеспечения национальной продовольственной безопасности Республики Беларусь. Вес. Нац. акад. навук Беларусі. Cер. аграр. Навук 3: 21-36 [Shpak Aleksandr Petrovich, Kirejenko Natal'ja Vladimirovna, Kondratenko Svetlana. 2017. Strategija i mechanizm obespechenija natsional'noj prodovol'stvennoj bezopasnosti Respubliki Belarus'. Best. Nats. Akad. Nauk. Belarusi. Ser. Agrar. Nauk 3.: 21-36]. 